\title{
Postpartum Severe Hyponatremia: a Rare Complication of Preeclampsia
}

\section{Postpartum Ciddi Hiponatremi: Preeklampsinin Nadir Bir Komplikasyonu}

\author{
Duygu Uçar ${ }^{1}$, Burcu Artunç Ülkümen ${ }^{1}$ \\ ${ }^{1}$ Manisa Celal Bayar Üniversitesi Kadın Hastalıkları ve Doğum Bölümü, Manisa, Türkiye \\ e-mail: eladuyguucar@gmail.com, artunc.burcu@gmail.com \\ ORCID: 0000-0003-4751-5944 \\ ORCID: 0000-0002-3128-8751 \\ *Sorumlu yazar/ Corresponding Author: Burcu Artunç Ülkümen \\ Gönderim Tarihi / Received: 09.07.2020 \\ Kabul Tarihi / Accepted: 23.09.2020 \\ DOI: $10.34087 /$ cbusbed.767056
}

Preeklampsi yüksek tansiyonlu gebelerde hem anne hem de yenidoğan için ölümcül olabilen ciddi bir sorundur. Literatürde preeklampsiye bağlı orta ve şiddetli hiponatremi insidansı az sayıda bildirilmesine rağmen perinatal ve maternal morbidite ve mortalitenin yüksek olmasıyla birliktelik gösteren önemli bir elektrolit bozukluğudur. Şiddetli hiponatremi ile komplike olan preeklampsi vakaları çok nadir olarak bildirilmiştir. Burada şiddetli hiponatremisi olan preeklamptik bir olguyu sunuyoruz ve bu nadir komplikasyonun patogenezini ve tedavisini kısaca tartış1yoruz.

Anahtar Kelimeler: Gebelik, Preeklampsi, Sodyum, hiponatremi

\begin{abstract}
Preeclampsia is a serious problem in pregnant women with high blood pressure, which can be fatal for both mother and newborn. Although the incidence of moderate and severe hyponatremia associated with preeclampsia has been reported in the literature in a small number, it is an important electrolyte disorder that may progress with high perinatal and maternal morbidity and mortality. Cases of preeclampsia complicated by severe hyponatremia have been reported much rarely. We present here a case with severe hyponatremia in preeclampsia and discuss shortly the pathogenesis and management of this rare complication.
\end{abstract}

Keywords: Preeclampsia, sodium, hyponatremia, pregnancy.

\section{Introduction}

Preeclampsia is an extremely dangerous syndrome with a wide range of signs and symptoms that can affect any organ system. Although proteinuria accompanying high blood pressure is the primary one; it can progress with important prodromal findings such as headache, edema, visual disturbances and epigastric pain.

Hyponatremia is a water and electrolyte balance disorder of which clinical outcomes can range from confusion to coma due to a decrease in plasma sodium concentration and result in serious neurological deficits. Hyponatremia can be roughly classified as hypovolemic, euvolemic, and hypervolemic. In hypovolemic hyponatremia, there is an increase in $\mathrm{ADH}$ release due to decreased intravascular water volume. Urine sodium level of $<10 \mathrm{mEq} / \mathrm{L}(10 \mathrm{mmol} / \mathrm{L})$ can be associated with this release . In euvolemic hyponatremia, the underlying cause of $\mathrm{ADH}$ may be due to malignant diseases or medications. In this case, urine sodium concentration is usually $>20 \mathrm{mEq} / \mathrm{L}(20 \mathrm{mmol} / \mathrm{L})$. In hypervolemic hyponatremia, the main problem is the increase in the amount of extracellular fluid and usually heart failure, cirrhosis and nephrotic syndrome. In these patients, urinary sodium concentration is generally $<10 \mathrm{mEq} / \mathrm{L}[1]$. Comparing pregnant women (whether or not complicated by preeclampsia) with healthy and non-pregnant women; 
significant differences between plasma electrolyte concentrations are not expected. Mild hyponatremia is an expected finding due to physiological changes during pregnancy. Increased $\beta$-human chorionic gonadotropin during pregnancy may cause an increase in free water retention by affecting the stimulation threshold of the osmoreceptors of antidiuretic hormone [2].

It typically occurs in the first 2 months of pregnancy, progresses as mild hyponatremia, and serum sodium levels are generally stable until birth. Therefore, intervention is not required. However, these processes in pregnancy physiology are not sufficient to explain the deep hyponatremia seen in a 26 -week pregnancy, as in our case.

Very few cases of deep hyponatremia accompanying patients with preeclampsia have been reported in the literature. It is observed that these cases mostly progress with hypervolemic hyponatremia. When serum sodium levels and urinary sodium excretions are examined, almost all of them are considered as inappropriate antidiuretic hormone release syndrome instead of nephrotic syndrome. The exact mechanism of inappropriate antidiuretic hormone release syndrome in the preeclampsia environment is still controversial [1].

Sutton et al. suggested that a defective placenta does not produce sufficient vasopressinase, a placental enzyme that inactivates $\mathrm{ADH}$ in patients with preeclampsia [3]. There are other theories on this subject. However, although its pathophysiology has not been fully elucidated, it has been understood that preeclamptic cases may be complicated by deep hyponatremia as in our case.

\section{Case Report}

A 32 year old patient who previously had only one miscarriage and was pregnant for 26 weeks and 3 days, was admitted to our facility with high blood pressure. The patient did not have previously diagnosed cardiological or nephrological diseases. There was also intrauterine growth restriction and oligohydroamniosis, which accompanied its current state.

At the time of hospitalization, serum sodium level was $136 \mathrm{mEq} / \mathrm{L}$; serum urea level was $25 \mathrm{mg} / \mathrm{dL}$; serum creatinine level was $0.58 \mathrm{mg} / \mathrm{dL}$; serum uric acid level was $5.3 \mathrm{md} / \mathrm{dL}$; serum potassium level was determined as $4.7 \mathrm{mEq} / \mathrm{L}$. 24-hour urine protein analysis was reported as $751.5 \mathrm{mg} / 24 \mathrm{~h}$. Liver function tests and platelet counts were measured in the normal range. The patient, who described prodromal findings, was taken to emergency cesarean and magnesium infusion was started.

Plasma sodium level was reported as $117 \mathrm{mEq} / \mathrm{L}$ in laboratory results after delivery. Fluid restriction was started and the patient was followed up closely. Control plasma sodium levels reported as $118 \mathrm{mEg} / \mathrm{L}$ and $120 \mathrm{mEq} / \mathrm{L}$ subsequently. Hypertonic sodium chloride infusion was initiated to the patient whose severe hyponatremia continued despite fluid restriction. Following a rapid increase of plasma sodium level, sodium chloride infusion was stopped in order to avoid central pontine myelinolysis in the patient.

The patient's plasma sodium level reached $123 \mathrm{mEq} / \mathrm{L}$ within 12 hours and $135 \mathrm{mEq} / \mathrm{L}$ within 48 hours. Sodium level in spot urine was measured as $58 \mathrm{mEq} / \mathrm{L}$ and the creatinine level in spot urine as $18.75 \mathrm{mg} / \mathrm{dL}$.

\section{Discussion}

Sodium concentration in urine increases in most preeclamptic patients. It is thought that the fractional excretion of sodium may be related to prerenal mechanisms [4]. Mild hyponatremia is considered among the physiological changes of pregnancy. However, the pathophysiology of severe hyponatremia on the background of preeclampsia is still unclear. Cases of severe hyponatremia, which have previously been accompanied by preeclampsia, have been reported in the literature rarely.

With the addition of hyponatremia to the dangerous picture already created by preclampsia, an extremely complicated situation arises that can be fatal for mother and baby. There still is not a clear correlation between coexistence of preeclampsia and hyponatremia with a tendency to have a seizure. However, this imbalance in sodium can pass to the fetus through the placenta and cause problems such as fetal jaundice, tachypnea and seizures [5]. Late diagnosis and delay in intervention may cause fatal outcomes for mother and baby. In addition, suppression of fetal ADH can increase fetal urine output and cause polyhydramniosis.

Therefore, awareness in terms of hyponatremia is extremely important during the management of preeclampsia. In order to avoid possible adverse outcomes of such situations, it may be an option to evaluate plasma sodium levels frequently in the management of preeclamptic patients. In this way, a serious metabolic disorder such as severe hyponatremia; with proper management and close follow-up, it can be overcome without complications. For those who do not respond only to the fluid restriction, oral sodium chloride should be added and attention to the premature delivery of the fetus.

It is not possible to reach a definitive conclusion due to the insufficiency of the studies and the reported cases. More studies are needed to reveal the true prevalence. 


\section{References}

1. Gagangeet, S, Senthil R, Chan, G, Meisels, I, Pathophysiology and Management of Preeclampsia-Associated Severe Hyponatremia, American Journal of Kidney Diseases : the Official Journal of the National Kidney Foundation, 11 Dec 2009, 55(3), 599-603

2. Cheung, K.L, Lafayette, R.A, Renal physiology of pregnancy, Advences in Chronic Kidney Diseases, 2013, 20, 209-214.

3. Sutton, R.A, Schonholzer, K, Kassen, B.O. Transient syndrome of inappropriate antidiuretic hormone secretion during pregnancy, American Journal of Kidney Diseases, 1993, 21(4), 444-445.

4. Robyn, H, Scott, R, Vanessa, R, Patricia, S.M, Kevin, W, Barbara, H, Williams Obstetrics, 24th Edition, Study Guide. Page;740

5. Larry Hinkson MBBS MD MRCOG FRCOG, Robert Armbrust MD, Annika Möller MD \& Wolfgang Henrich MD PhD (2017): Case report of severe maternal hyponatremia complicating preeclampsia The Journal of Maternal-Fetal \& Neonatal Medicine 2017, 31, 14,1-

2 .

http://edergi.cbu.edu.tr/ojs/index.php/cbusbed isimli yazarın CBU-SBED başlıklı eseri bu Creative Commons Alınt1-Gayriticari4.0 Uluslararası Lisansı ile lisanslanmıştır.

cc) (7) (3) 